\title{
Remnant Freshwater Mussel Diversity in Rondeau Bay, Lake Erie
}

\author{
Scott M. Reid ${ }^{1,3}$, Victoria Kopf ${ }^{1}$, Anita LeBaron $^{1}$, and Todd J. Morris ${ }^{2}$ \\ ${ }^{1}$ Aquatic Research and Monitoring Section, Ontario Ministry of Natural Resources and Forestry, Trent University, DNA Building, \\ 2140 East Bank Drive, Peterborough, Ontario K9J 7B8 Canada \\ ${ }^{2}$ Great Lakes Laboratory for Fisheries and Aquatic Sciences, Fisheries and Oceans Canada, Burlington, Ontario L7S 1A1 Canada \\ ${ }^{3}$ Corresponding author: reid.scott@ontario.ca
}

Reid, Scott M., Victoria Kopf, Anita LeBaron, and Todd J. Morris. 2016. Remnant freshwater mussel diversity in Rondeau Bay, Lake Erie. Canadian Field-Naturalist 130(1): 76-81.

In 2014 and 2015, 27 sites in Rondeau Bay, Ontario, Canada, were surveyed for freshwater mussels. Rondeau Bay is a large coastal wetland on the north shore of Lake Erie. Twenty-three species were identified from 120 live mussels, 15 fresh whole shells, 329 weathered whole shells, and 1121 weathered valves. Live individuals of the following species were collected: Eastern Pondmussel (Ligumia nasuta; endangered in Canada), Giant Floater (Pyganodon grandis), Round Pigtoe (Pleurobema sintoxia; endangered in Canada), and Three-ridge (Amblema plicata). Fresh whole shells of the Mapleleaf (Quadrula quadrula; threatened in Canada) were also found. Most species (78\%), including 7 species at risk, were collected only as weathered shells. These results indicate a substantial decline in freshwater mussel diversity since the Zebra Mussel (Dreissena polymorpha) invasion of Lake Erie. Evidence shows that a viable population of only Giant Floater remains.

Key Words: Freshwater mussels; Unionidae; unionids; species at risk; Zebra Mussel; Dreissena polymorpha; Rondeau Bay; Lake Erie; wetland; refuge; Giant Floater; Pyganodon grandis

\section{Introduction}

The invasion of the Laurentian Great Lakes basin by dreissenid mussels — Zebra Mussel (Dreissena polymorpha Pallas, 1771) and Quagga Mussel (D. bugensis Andrusov, 1897) - has resulted in substantial and widespread declines in native mussel abundance and diversity (Schloesser and Nalepa 1994). By the early 1990s, native mussels were nearly extirpated from offshore waters in lakes Erie and St. Clair (Metcalfe-Smith et al. 2005). Over the past 15 years, an increasing number of studies have demonstrated the importance of Great Lakes coastal wetlands to freshwater mussel conservation. Compared with adjacent open water habitat, wetlands are less suitable for dreissenid colonization and survival (Bowers and Szalay 2003; Sherman et al. 2013) and, thus, provide a refuge for native mussels. Remnant mussel assemblages have been identified in coastal areas of lakes Erie, Huron, Ontario, and St. Clair (Zanatta et al. 2002; Bowers and Szalay 2003; Sherman et al. 2013; Reid et al. 2014; Zanatta et al. 2015).

Although intensive, semi-quantitative inventories of unionid mussels have recently been carried out in coastal wetlands along the western and southern shores of Lake Erie (Zanatta et al. 2015), similar efforts have not been undertaken in Canadian waters. In 2014 and 2015, targeted surveys for 2 Canadian species at risk, Rainbow Mussel (Villosa iris (Lea, 1829)) and Eastern Pondmussel (Ligumia nasuta (Say, 1817)), were conducted in Rondeau Bay to inform species status assessments and delineation of protected habitats. Rondeau Bay $\left(42^{\circ} 17^{\prime} 35^{\prime \prime} \mathrm{N}, 81^{\circ} 53^{\prime} 24^{\prime \prime} \mathrm{W}\right)$ is a large $\left(37 \mathrm{~km}^{2}\right)$, shallow (maximum depth $3 \mathrm{~m}$ ) coastal embayment and wetland complex with abundant submerged macrophyte growth, on the north shore of Lake Erie. The bay is bounded by Rondeau Provincial Park on the east and connected to the central basin of Lake Erie through a navigation channel. Occasional mussel surveys have occurred in Rondeau Bay over the past 120 years, with the last effort described as, "largely fruitless" (Zanatta et al. 2002).

\section{Methods}

In 2014, 12 sites were sampled from 24 to 26 June (Figure 1). Site selection was based on historical Rainbow Mussel collection records (Lower Great Lakes Unionid Database, Fisheries and Oceans Canada) and the occurrence of sand and gravel habitat, which is suitable for Rainbow Mussel (Metcalfe-Smith et al. 2005). At these sites, the lake bed substrate was visually assessed as $71 \%$ sand and gravel and $29 \%$ clay, silt, and organics (mean values). In 2015, 15 sites were sampled from 22 to 25 June (Figure 1). Habitat selection in 2015 was informed by past experience collecting Eastern Pondmussel (Reid et al. 2014). Compared with the 2014 sites, the lake bed of sites surveyed in 2015 had less sand and gravel ( $20 \%$ of substrate composition) and more clay, silt, and organics (80\%). Depths of soft sediment were also greater (up to $0.5 \mathrm{~m}$ versus up to $0.2 \mathrm{~m}$ ). Combined, sites were widely distributed along the entire shoreline of the bay and represented a variety of habitats.

Each site was searched for 4.5 person-hours (Metcalfe-Smith et al. 2000) using a visual-tactile sampling method (Reid et al. 2014). Visual-tactile searching involved either floating on an air mattress and hand searching the sediment for mussels (both on the surface and probing through sediment for burrowed mussels) 


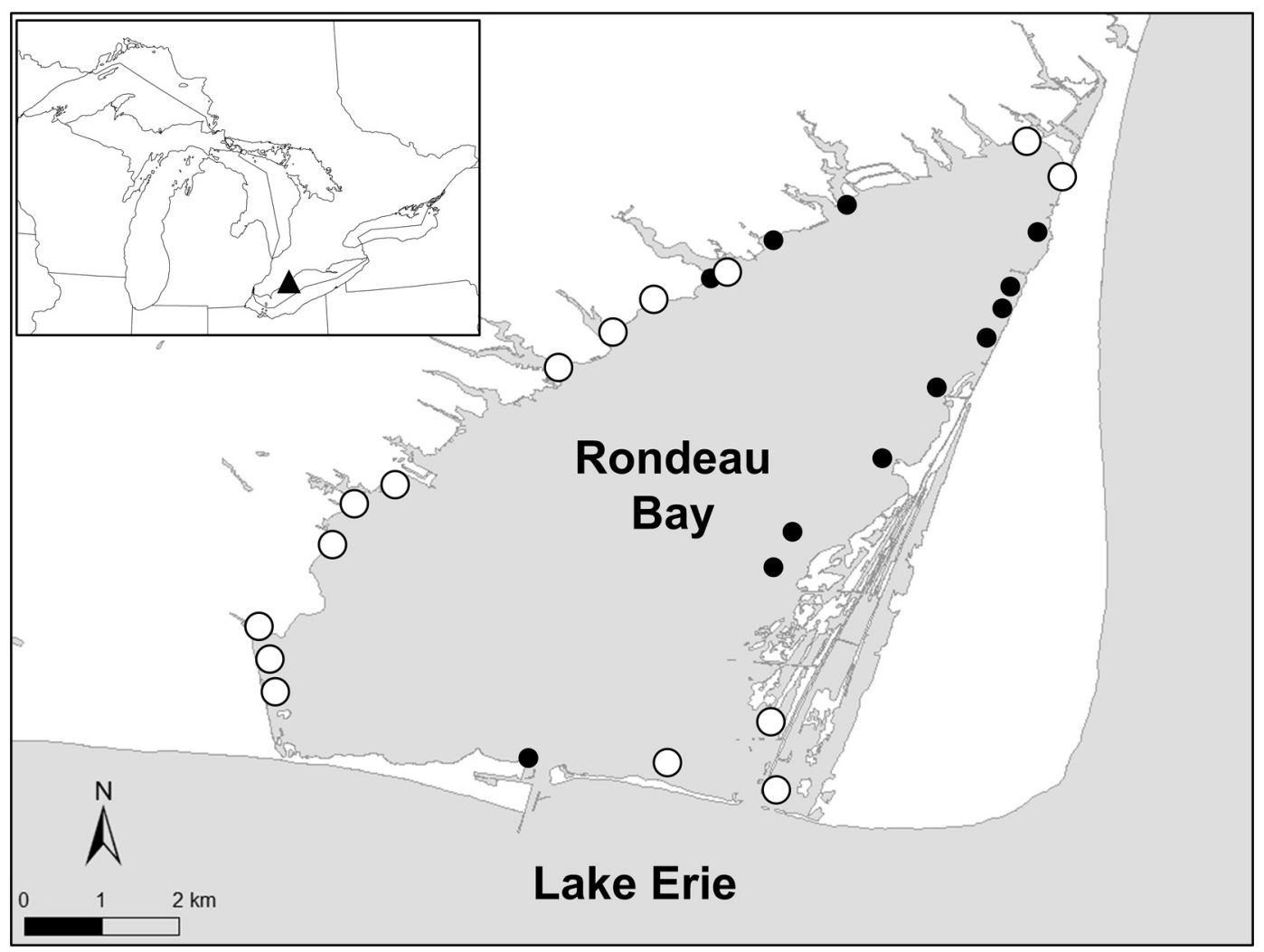

FigurE 1. Location of 2014 (•) and 2015 (○) freshwater mussel sampling sites in Rondeau Bay, Lake Erie, Ontario.

or searching for mussels with a 0.33-m diameter underwater viewer (Plastimo Round Underwater Viewer Nuova Rade, Busalla, Italy) or polarized lenses. Water depths at searched habitats were between 0.15 and $1.50 \mathrm{~m}$. Live mussels and shells were identified to species (Metcalfe-Smith et al. 2005). Shell length (mm) of live mussels was measured with a dial caliper $( \pm 0.1 \mathrm{~mm})$. Live mussels and attached dreissenids were weighed separately $( \pm 0.1 \mathrm{~g})$. After processing, live mussels were returned to the sediment.

\section{Results}

Twenty-three species were identified among 120 live mussels, 15 fresh whole shells, 329 weathered whole shells, and 1123 weathered valves (Table 1). Excessive shell degradation made 912 weathered shells and shell fragments impossible to identify. Most species (78\%), including 7 species at risk, were identified from weathered shells and valves only. Weathered shell material was dominated numerically at the tribe level by Lampsilini ( $82 \%$ of collection) and at the species level by Fatmucket (Lampsilis siliquoidea (Barnes, 1823); 60\% of collection), Wabash Pigtoe (Fusconaia flava (Rafinesque, 1820); 10\%), Deertoe (Truncilla truncata
(Rafinesque, 1820); 9\%), Pink Heelsplitter (Potamilus alatus (Say, 1817); 5\%), and Mapleleaf (Quadrula quadrula (Rafinesque, 1820); 3.5\%). A single, weathered Rainbow Mussel valve was found. Only species from the tribes Alasmidontini, Pleurobemini, and Quadrulini were identified from fresh whole shells, including the threatened Mapleleaf and endangered Round Pigtoe (Pleurobema sintoxia (Rafinesque, 1820)). Substantially more shell material was collected in 2014 than in 2015. Correspondingly, 4 times as many species were identified from shell material in 2014 (median $=8$, range $=1-12)$ than in 2015 (median $=2$, range $=0-6)$.

Despite the intensive search effort $(>120 \mathrm{~h})$, live mussels from only 4 species - Eastern Pondmussel, Giant Floater (Pyganodon grandis (Say, 1829)), Round Pigtoe, and Three-ridge (Amblema plicata (Say, 1817)) - were collected. Based on abundance, the current mussel assemblage is almost exclusively Giant Floater (97.5\%, Table 1). Almost all live Giant Floaters were collected in 2015; of these, $84 \%$ were collected from 4 sites along the western shoreline. A wide range of Giant Floater shell lengths indicates ongoing population recruitment (Figure 2). Dreissenids were attached to $88 \%$ of live mussels (all 4 species) and found at most 


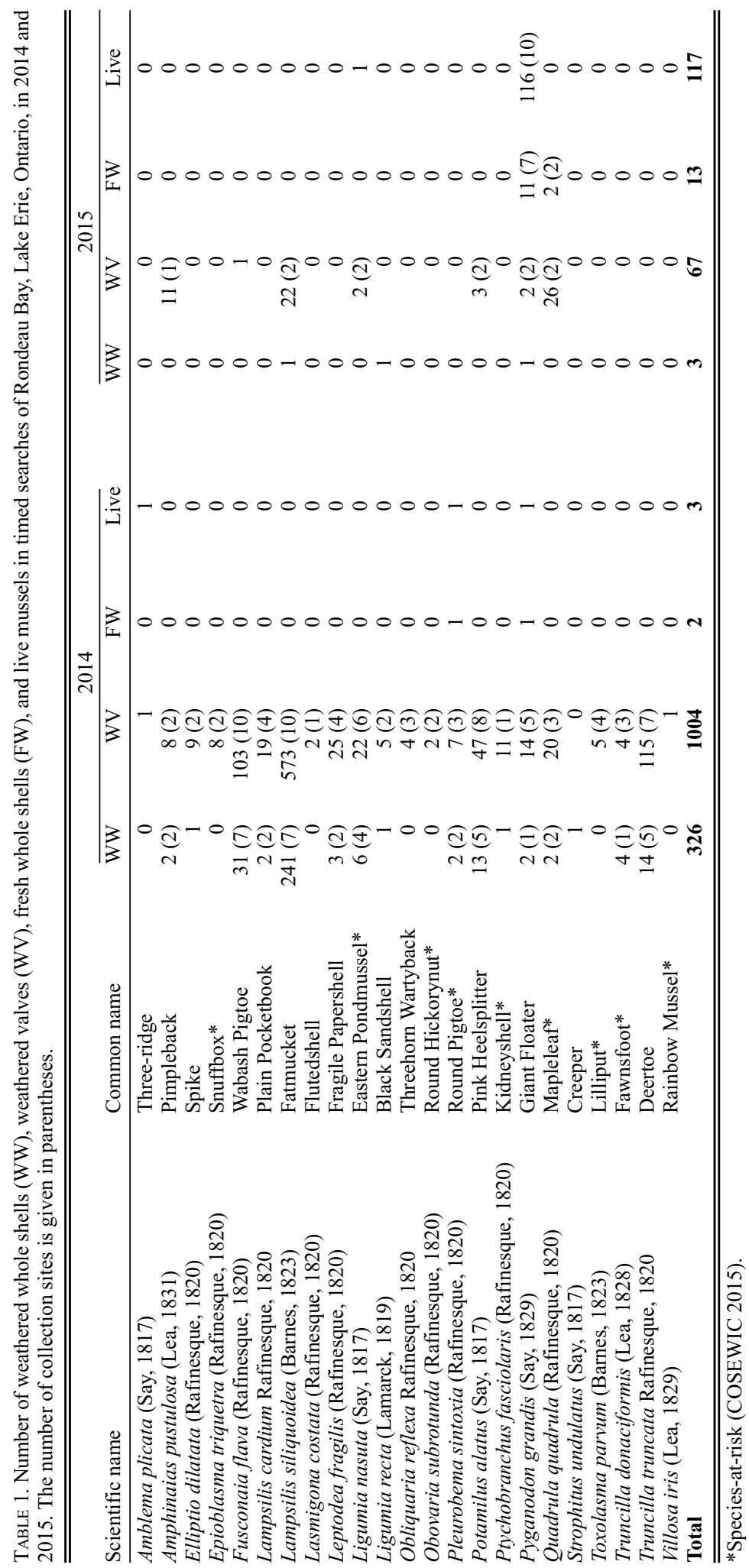




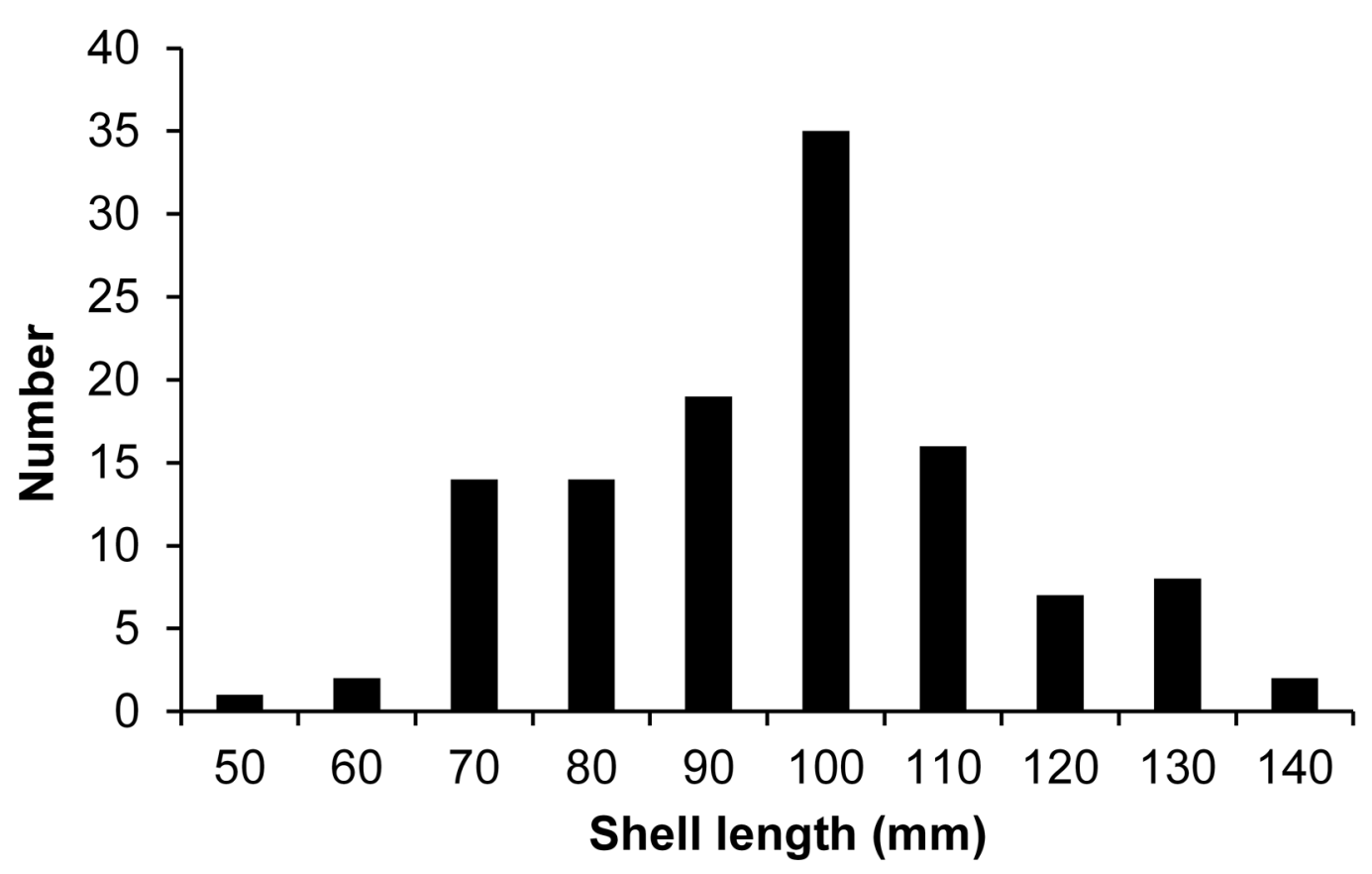

FIGURE 2. Frequency distribution of shell length of the 117 live Giant Floaters (Pyganodon grandis) collected from Rondeau Bay, Lake Erie, Ontario, in 2014 and 2015.

sites $(89 \%)$. Up to $79 \mathrm{~g}$ of dreissenids were removed from individual live mussels. The mass ratio of attached dreissenids to live mussel ranged from 0.0009 to 1.393 $($ median $=0.0422)$.

\section{Discussion}

In this study, shell material from $70 \%$ of the species known from the Canadian waters of Lake Erie (Metcalfe-Smith et al. 1998) was found, more species than found in previous surveys in Rondeau Bay (Table 2). Except for Cylindrical Papershell (Anodontoides ferussacianus (Lea, 1834)), all species previously reported from Rondeau Bay were detected. Before the Zebra Mussel invasion of Lake Erie (about 1989), 15 species had been collected from Rondeau Bay, of which 9 belonged to the tribe Lampsilini. Subsequent sampling identified 9 additional species and suggested that a more balanced representation of species from all 5 tribes was historically present (Table 2). Most (89\%) of these new records, however, were associated with weathered shells. The large amount of shell material encountered during this study is likely the result of high mortality of native mussels following the Zebra Mussel colonization of Rondeau Bay (Schloesser et al. 1996) and likely offset the poor detectability typical of many freshwater mussel species (Strayer and Smith 2003).
The remaining, depauperate mussel fauna in Rondeau Bay includes small numbers of 3 species-at-risk and 1 abundant species. Mussel diversity and densities are much lower than in important refuges identified in the western basin of Lake Erie and the Lake St. Clair delta (McGoldrick et al. 2009; Zanatta et al. 2015). The abundance and richness of Rondeau Bay mussels is comparable to assemblages in the large, shallow region of Sandusky Bay and the south shore, central basin Lake Erie wetlands (Zanatta et al. 2015).

As reported for other Lake Erie and Ontario coastal wetlands, an abundant Giant Floater population is present in Rondeau Bay. The species' persistence after the Zebra Mussel invasion can be attributed to its opportunistic life history strategy (high fecundity, early age of reproduction, and short life-span; Haag 2012) and its association with habitats, i.e., soft substrates, that are not well suited for Zebra Mussel and allow for native mussels to burrow (Bowers and Szalay 2003; Zanatta et al. 2015). Low density populations of mussels at risk have also been detected in north shore Lake Ontario coastal wetlands (Reid et al. 2014). However, the viability of such small populations is uncertain. Our study highlights the need for further, intensive sampling of north shore Lake Erie wetlands to document the viability of other remnant populations of mussel species at risk. 
TABLE 2. Comparison of Rondeau Bay mussel species collected in 6 surveys between 1894 and 2015. Historical records are from the Canadian Museum of Nature, the University of Michigan Museum of Zoology, the Royal Ontario Museum, and Environment Canada collections.

\begin{tabular}{|c|c|c|c|c|c|c|}
\hline Common name & 1894 & 1934 & $1961-65$ & 1988 & 2001 & $2014-15$ \\
\hline \multicolumn{7}{|l|}{ SUBFAMILY AMBLEMINAE } \\
\hline \multicolumn{7}{|l|}{ TRIBE AMBLEMINI } \\
\hline Three-ridge & & & & & $\mathrm{L}$ & $\mathrm{L}$ \\
\hline \multicolumn{7}{|l|}{ TRIBE LAMPSILINI } \\
\hline Black Sandshell & & & & & W & $\mathrm{W}$ \\
\hline Fawnsfoot & & & & $\mathrm{L}$ & W & $\mathrm{W}$ \\
\hline Deertoe & & & $*$ & $\mathrm{~L}$ & W & W \\
\hline Eastern Pondmussel & $\mathrm{L}$ & $\mathrm{L}$ & $*$ & $\mathrm{~L}$ & W & $\mathrm{L}$ \\
\hline Fatmucket & $\mathrm{L}$ & $\mathrm{L}$ & $\mathrm{L}$ & $\mathrm{L}$ & $\mathrm{W}$ & $\mathrm{W}$ \\
\hline Fragile Papershell & & $\mathrm{L}$ & $\mathrm{L}$ & $\mathrm{L}$ & W & $\mathrm{W}$ \\
\hline Kidneyshell & & & & & W & $\mathrm{W}$ \\
\hline Lilliput & & & & & & W \\
\hline Pink Heelsplitter & $\mathrm{L}$ & $*$ & & & W & $\mathrm{W}$ \\
\hline Plain Pocketbook & & $\mathrm{L}$ & $*$ & & W & W \\
\hline Rainbow & & $\mathrm{L}$ & $*$ & & & W \\
\hline Round Hickorynut & & & & & & $\mathrm{W}$ \\
\hline Snuffbox & $\mathrm{L}$ & * & $*$ & & W & $\mathrm{W}$ \\
\hline Threehorn Wartyback & & & & & $\mathrm{L}$ & W \\
\hline \multicolumn{7}{|l|}{ Tribe PleurobeminI } \\
\hline Round Pigtoe & & & $*$ & & W & $\mathrm{L}$ \\
\hline Spike & & & & & & $\mathrm{W}$ \\
\hline Wabash Pigtoe & & & $\mathrm{L}$ & $\mathrm{L}$ & W & W \\
\hline \multicolumn{7}{|l|}{ TRIBE QUADRULINI } \\
\hline Mapleleaf & $\mathrm{L}$ & & $*$ & & $\mathrm{~W}$ & $\mathrm{~L}$ \\
\hline Pimpleback & & * & & & & W \\
\hline \multicolumn{7}{|l|}{ SUBFAMILY UNIONINAE } \\
\hline \multicolumn{7}{|l|}{ TRIBE AlasmidOntinI } \\
\hline Creeper & & & & & & W \\
\hline Cylindrical Papershell & & $\mathrm{L}$ & & & & \\
\hline Flutedshell & & & & & W & $\mathrm{W}$ \\
\hline Giant Floater & $\mathrm{L}$ & $\mathrm{L}$ & $\mathrm{L}$ & $\mathrm{L}$ & W & $\mathrm{L}$ \\
\hline Total number of species & 6 & 10 & 11 & 7 & 17 & 23 \\
\hline
\end{tabular}

Note: $\mathrm{L}=$ live mussel or fresh whole shell, $\mathrm{W}=$ weathered shell or valve, $*=$ no description of material provided with record.

\section{Acknowledgements}

This research was supported by funding from Environment Canada, Fisheries and Oceans Canada, and the Ontario Ministry of Natural Resources and Forestry. Christine Head, Fielding Montgomery, Mike Parna, Hailey Smith, and Jenna Snelgrove assisted with sampling. The manuscript was improved with comments from 3 anonymous reviewers.

\section{Literature Cited}

Bowers, R., and F. Szalay. 2003. Effects of hydrology on unionids (Unionidae) and Zebra Mussels (Dreissenidae) in a Lake Erie coastal wetland. American Midland Naturalist 151: 286-300.

COSEWIC (Committee on the Status of Endangered Wildlife in Canada). 2015. Canadian Wildlife Species at Risk. COSEWIC, Environment Canada, Gatineau, Quebec, Canada. Accessed 12 September 2015. http://www.cosewic .gc.ca/eng/sct0/rpt/csar_fall_2015_e.pdf.

Haag, W. R. 2012. North American Freshwater Mussels. Natural History, Ecology, and Conservation. Cambridge University Press, Cambridge, UK.
McGoldrick, D. J., J. L. Metcalfe-Smith, M. T. Arts, D. W. Schloesser, T. J. Newton, G. L. Mackie, E. M. Monroe, J. Biberhofer, and K. Johnson. 2009. Characteristics of a refuge for native freshwater mussels (Bivalvia: Unionidae) in Lake St. Clair. Journal of Great Lakes Research 35: 137-146.

Metcalfe-Smith, J. L., S. K. Staton, G. L. Mackie, and N. M. Lane. 1998. Changes in the biodiversity of freshwater mussels in the Canadian waters of the Lower Great Lakes drainage basin over the past 140 years. Journal of Great Lakes Research 24: 845-858.

Metcalfe-Smith, J. L., J. Di Maio, S. K. Staton, and G. L. Mackie. 2000. Effect of sampling effort on the efficiency of the timed search method for sampling freshwater mussel communities. Journal of the North American Benthological Society 19: 725-732.

Metcalfe-Smith, J. L., A. MacKenzie, I. Carmichael, and D. McGoldrick. 2005. Photo field guide to the freshwater mussels of Ontario. St. Thomas Field Naturalist Club, St. Thomas, Ontario, Canada.

Reid, S. M., A. Brumpton, S. Hogg, and T. Morris. 2014. A comparison of two timed search methods for collecting freshwater mussels in Great Lakes coastal wetlands. Walkerana 17: 16-23. 
Schloesser, D. W., and T. F. Nalepa. 1994. Dramatic decline of unionid bivalves in the offshore waters of western Lake Erie after infestation by the zebra mussel, Dreissena polymorpha. Canadian Journal of Fisheries and Aquatic Sciences 51: 2234-2242.

Schloesser, D. W., T. F. Nalepa, and G. L. Mackie. 1996. Zebra mussel infestation of unionid bivalves (Unionidae) in North America. American Zoologist 36: 300-310.

Sherman, J. J., B. A. Murry, D. A. Woolnough, D. T. Zanatta, and D. G. Uzarski. 2013. Assessment of remnant unionid assemblages in a selection of Great Lakes coastal wetlands. Journal of Great Lakes Research 39: 201-210.

Strayer, D. L., and D. R. Smith. 2003. A guide to sampling freshwater mussel populations. Monograph 8. American Fisheries Society, Bethesda, Maryland, USA.
Zanatta, D. T., G. L. Mackie, Metcalfe-Smith, J. L., and D. A. Woolnough. 2002. A refuge for native freshwater mussels (Bivalvia: Unionidae) from impacts of the exotic zebra mussel (Dreissena polymorpha) in Lake St. Clair. Journal of Great Lakes Research 28: 479-489.

Zanatta, D. T., J. M. Bossenbroek, L. E. Burlakova, T. D. Crail, F. de Szalay, T. A. Griffith, D. Kapusinski, A. Y. Karateyev, R. A. Krebs, E. S. Meyer, W. L. Paterson, T. J. Prescott, M. T. Rowe, D. W. Schloesser, and M. C. Walsh. 2015. Distribution of native mussel (Unionidae) assemblages in coastal Lake Erie, Lake St. Clair, and connecting channels, twenty-five years after the dreissenid invasion. Northeastern Naturalist 22: 223-235.

Received 6 October 2015

Accepted 5 February 2016 